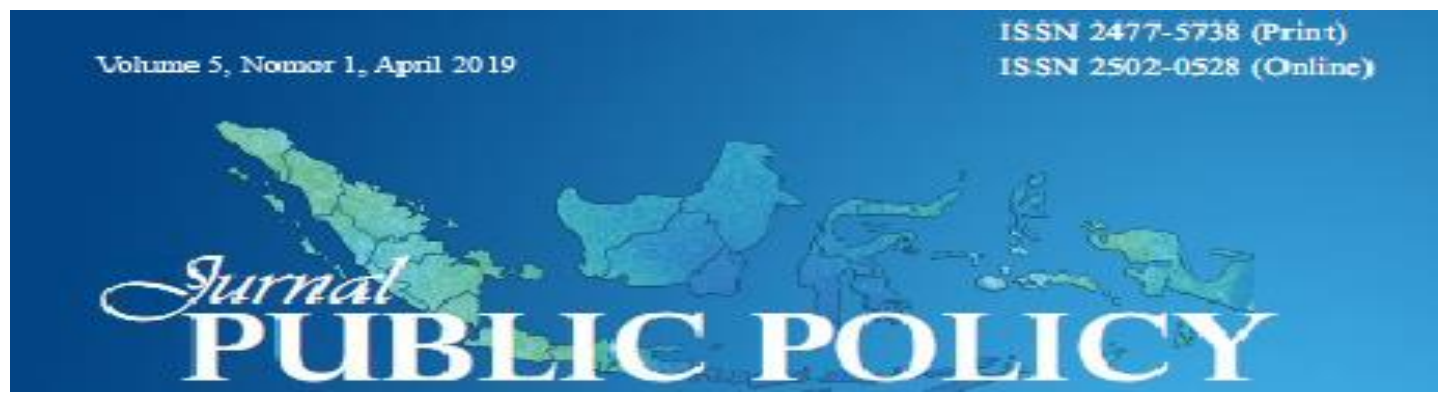

Journal homepage: http//:jurnal.utu.ac.id/jppolicy

\title{
PERAN PEMERINTAH ACEH BARAT DALAM MENGATASI LIMBAH INDUSTRI
}

\author{
Yeni Sri Lestari ${ }^{1}$ Putri Keumalasari $^{2}$ \\ Fakultas Ilmu Sosial dan Ilmu Politik Universitas Teuku Umar \\ 1yenilestari24@yahoo.com \\ 2putrikeumalasari@utu.ac.id
}

\begin{abstract}
Abstrak
Kajian ini penting untuk dibahas karena tanggung jawab moral pemerintah adalah memastikan penyelenggaraan pemerintahan yang baik kepada masyarakat luas. Salah satunya adalah jaminan untuk mendapatkan lingkungan yang bersih dan menjamin kesehatan masyarakat. Keberadaan industri cenderung memberikan sisi positif bagi memajukan perekonomian daerah, namun hal tersebut seringkali tidak diimbangi dengan analisis dampak lingkungan yang komprehensif, sehingga menjadikan masyarakat sebagai korban dari industrialisasi, salah satunya seperti yang terjadi di Aceh Barat. Keberadaan PT. Mifa Bersaudara menimbulkan persoalan lingkungan disekitar masyarakat. Oleh karena itu, kajian ini akan mengkaji mengenai bagaimanakah upaya dan program kerja yang dilakukan pemerintah Aceh Barat dalam menanggulangi masalah limbah batu bara PT. Mifa Bersaudara?, dan bagaimana respon PT. Mifa Bersaudara terhadap keluhan dari masyarakat?. Dari hasil penelitian ditemukan bahwa Pemerintah Aceh Barat bekerjasama dengan seluruh instansi pemerintah serta aktivis peduli lingkungan telah aktif dalam mengupayakan dan mengagendakan berbagai program kerja untuk menyelesaikan permasalahan ini. Sedangkan PT. Mifa sendiri secara aktif sudah melaksanakan tanggungjawabnya dalam menjaga lingkungan sekitar industri melalui pelaksanaan CSR.
\end{abstract}

Keywords: Peran, Pemerintah, Limbah Industri 


\section{PENDAHULUAN}

Keberadaan industri pada dasarnya bertujuan untuk mengelola sumber daya yang terdapat di suatu wilayah dengan semaksimal mungkin memberikan manfaat besar bagi kehidupan masyarakat seperti tersedianya lapangan kerja, programprogram pemberdayaan masyarakat serta hal-hal positif lainnya bertujuan untuk sama-sama mendapatkan manfaat dari pengelolaan sumber daya yang ada. Namun, keberadaan industri tidak selalu memberikan manfaat positif bagi masyarakat disekitarnya, hal ini dikarenakan masih banyak dijumpai masalah lingkungan akibat berdirinya sebuah industri, terutama dalam pengelolaan limbah industri.

Aceh Barat, merupakan salah satu wilayah di Provinsi Aceh yang memiliki potensi sumber daya alam yang melimpah, salah satunya adalah pengelolaan batu bara yang dimanfaatkan untuk mendukung suplai listrik di wilayah Aceh hingga Medan. Sehingga, industri batu bara memiliki potensi besar bagi pemasukkan Pendapatan Asli Daerah (PAD) dan membuka lapangan kerja untuk memberdayakan masyarakat di Aceh Barat.

PT Mifa Bersaudara yang disahkan melalui Surat Keputusan Menteri Hukum dan HAM RI No.C-03647.HT.01.01TH.2002 resmi beroperasi di Kabupaten Aceh Barat Provinsi Aceh yang bergerak di bidang pertambangan batu bara. Banyak program pemberdayaan masyarakat yang telah dijalankan oleh industri ini untuk mendukung proses pembangunan di wilayah Aceh Barat. Namun, hal tersebut masih belum menunjukkan hasil yang maksimal bagi kalangan masyarakat sekitar lokasi penambangan.

Persoalan limbah industri dan polusi yang ditimbulkan sebagai bagian dari proses penambangan batu bara menjadi akar konflik yang cenderung terjadi antara industri dan masyarakat sekitar. Keluhan masyarakat mengenai gangguan pernapasan akibat debu batu bara mengharuskan pemerintah Aceh Barat untuk turut serta menyelesaikan persoalan tersebut.

Industrialisasi merupakan proses pembangunan yang berada pada satu jalur kegiatan berupa upayanya untuk meningkatkan kualitas hidup dan kesejahteraan masyarakat, di mana pada prosesnya tidak terlepas dari tujuannya untuk meningkatkan mutu sumber daya manusia dan sumber daya alam. Namun, pada perkembangan keberadaan industri memunculkan persoalan tersendiri mengenai kerusakan lingkungan (Ima Maghfiro, dkk. 94-102). Kerusakan lingkungan akibat industri seringkali berupa pengelolaan limbah yang belum maksimal ditangani sehingga memunculkan konflik antara industri dengan masyarakat sekitar.

Lingkungan hidup merupakan aset vital bagi masyarakat, baik buruknya kondisi lingkungan hidup akan memberikan pengaruh terhadap kehidupan sosial masyarakat. Eksploitasi lingkungan hidup untuk menunjang pembangunan harus diselaraskan dengan kondisi sosial masyarakat, karena lingkungan hidup sebagai objek pengaturan dilindungi dari perbuatan manusia agar interkasi antara keduanya harmonis, serasi dan saling mendukung (Siahaan, 2008: 43). Oleh karena itu, upaya untuk membangun integritas antara pemerintah, industri dan masyarakat untuk mewujudkan pembangunan yang berkelanjutan harus disinkronkan mulai dari 
tahapan awal hingga akhir, agar tercipta suasana lingkungan hidup yang mampu memberikan manfaat besar bagi kehidupan masyarakat dan daerah.

Kerja sama antar kalangan untuk mewujudkan pembangunan berkelanjutan harus didukung dengan kebijakan pemerintah daerah dalam mengawal, mengontrol dan menindak setiap kegiatan industri dan masukkan dari masyarakat luas. Pentingnya peran pemerintah dalam mengatasi isu limbah PT. Mifa Bersaudara menjadi indikator kinerja pemerintah di mata masyarakat.

Peran pemerintah perlu dilihat sebagai political will untuk membangun daerah beserta masyarakat daerahnya secara berimbang, sehingga kepercayaan masyarakat terhadap pemerintah dapat menunjang kinerja pemerintah dalam pembangunan. Penelitian ini langsung melibatkan masyarakat sebagai subjek penelitian sehingga dapat membantu dan mengarahkan peneliti untuk melihat langsung persoalan yang dihadapi oleh masyarakat dan kebijakan yang ditawarkan oleh pemerintah.

\section{TINJAUAN PUSTAKA}

Peran dalam Kamus Besar Bahasa Indonesia memiliki arti sebagai perangkat tingkah yang diharapkan dimiliki oleh orang yang berkedudukan dalam masyarakat (https://kbbi.web.id/peran). Istilah peran berasal dari dunia teater (Hutami, 2011) yang diibaratkan sebagai seorang aktor harus bermain sebagai tokoh tertentu yang memiliki posisi dan diharapkan untuk berperilaku secara tertentu juga.

Kedudukan aktor dalam sebuah teater digambarkan sebagai seseorang yang memiliki posisi tertentu di dalam masyarakat. Begitupun gambaran yang dianalogikan bagi posisi masyarakat dalam sebuah kelompok sebagai aktor yang dalam perilakunya selalu berkaitan dengan orang lain, karena aktor dalam teater muncul atas arahan dari orang-orang lain yang berhubungan dengannya. Sehingga apa yang dilakukan oleh aktor yang menjalankan fungsinya sebagai masyarakat akan selalu dikaitkan dengan orang yang terlibat dengannya.

Peran (Amrianto, 2014) adalah suatu konsep perilaku apa yang dapat dilakukan oleh individu-individu dalam masyarakat sebagai organisasi. Peran juga dapat dikatakan sebagai perilaku individu yang penting bagi struktur sosial masyarakat. Oleh karena itu, peran dalam struktur sosial masyarakat sebagai sebuah kelompok (organisasi, asosiasi, himpunan) memiliki peran yang lebih besar atas status atau kedudukannya.

Latar belakang dari istilah peran tersebut kemudian berkembang menjadi landasan terbentuknya sebuah teori peran (role theory). Teori peran dikembangkan oleh seorang Antropolog bernama Robert Linton (1936, dalam Cahyono, 2008), Linton menggambarkan teori peran sebagai interaksi sosial dalam terminologi aktoraktor yang bermain sesuai dengan apa yang telah ditetapkan oleh budaya. 
Peran yang melekat pada diri seseorang diharapkan dapat mencerminkan perilaku seseorang tersebut dalam kehidupan sehari-hari. Andaian ini menjadi kesimpulan bersama dalam masyarakat luas, bahwa label peran yang melekat pada individu harus dijalankan sesuai dengan peran yang ia lakonkan, seperti halnya sosok ayah. Ayah dalam pandangan masyarakat haruslah berperan sebagaimana seharusnya seorang ayah berperilaku yaitu mencari nafkah dan mengayomi keluarganya.

Teori peran dalam politik digunakan karena dua alasan (Folarin, 2010). Pertama, teori peran mampu memahami perilaku kelompok yang terlibat dalam pengambilan keputusan dan kedua, teori peran dapat digunakan dengan mengabaikan sistem politik yang lebih besar (sistem internasional) dengan memahami persepsi pengambil kebijakan terhadap harapan peran. Namun, meskipun begitu pada dasarnya teori peran sangat memberikan pengaruh dalam setiap pengambilan kebijakankebijakan politik baik dalam level terkecil seperti desa hingga level besar seperti hubungan dengan negara lain.

Teori peran politik (Amrianto, 2014) menegaskan bahwa perilaku politik adalah perilaku yang dijalankan oleh aktor politik dalam peranan politik. Perilaku politik ini muncul disebabkan tuntutan dan harapan terhadap peran yang dipegang oleh aktor politik seperti menduduki posisi tertentu. Peran politik yang dilakukan oleh aktor politik tentunya juga memberikan konsekuensi politik yang mencakup masyrakat luas seperti produk kebijakan.

Ketentuan Umum Pasal 1 dalam Undang-undang Pemerintahan Daerah Nomor 23 Tahun 2014 menyatakan bahwa pemerintah daerah adalah kepala daerah sebagai unsur penyelenggaraan pemerintahan daerah yang memimpin pelaksanaan urusan pemerintahan yang menjadi kewenangan daerah otonom. Pemerintahan daerah adalah penyelenggaraan urusan pemerintahan oleh pemerintah daerah dan dewan perwakilan rakyat daerah menurut asas otonomi dan tugas pembantuan dengan prinsip otonomi seluas-luasnya dalam sistem dan prinsip Negara Kesatuan Republik Indonesia sebagaimana dimaksud dalam Undang-undang Dasar Negara Republik Indonesia Tahun 1945.

Pemerintah daerah dalam wilayah otonom memiliki kewenangan untuk mengatur rumah tangga daerahnya sendiri. Dalam melaksanakan kewenangan tersebut, pemerintahan daerah berpedoman kepada 3 asas penyelenggaraan pemerintahan daerah yaitu pertaman, asas desentralisasi yang merupakan penyerahan sejumlah urusan pemerintahan dari pemerintah pusat atau dari pemerintahan daerah tingkat yang lebih tinggi kepada daerah tingkat yang lebih rendah. Kedua, asas dekonsentrasi yang merupakan pelimpahan wewenang dari aparat pemerintahan pusat atau pejabat di atasnya. Ketiga, asas tugas pembantuan yaitu asas yang menyatakan tugas turur serta dalam pelaksanaan urusan pemerintahan yang ditugaskan kepada 
pemerintah daerah dengan kewajiban mempertanggungjawabkannya kepada yang memberi tugas.

Pemerintah daerah dalam menyelenggarakan pemerintahan daerah demi tercapainya pelaksanaan otonomi daerah yang berimbang harus mengurus urusan daerah dan kepentingan masyarakat setempat sesuai dengan peraturan perundangundangan. Pembagian urusan pemerintahan daerah juga diatur dalam Undang-undang Nomor 23 Tahun 2014 yang dibagi dalam 3 kategori, yaitu Urusan Pemerintahan Absolut, Urusan Pemerintahan Konkuren, dan Urusan Pemerintahan Umum.

Urusan pemerintahan Absolut merupakan urusan pemerintahan yang sepenuhnya menjadi kewenangan Pemerintah Pusat. Urusan pemerintahan ini meliputi politik luar negeri, pertahanan, keamanan, yustisi, moneter dan fiskal, serta agama. Dalam urusan ini, pemerintah pusat berwenang luas untuk mengurusnya, tetapi pemerintah pusat juga memiliki pilihan untuk melimpahkan wewenang tersebut kepada daerah berdasarkan asas dekonsentrasi.

Urusan pemerintahan konkuren adalah urusan pemerintahan yang dibagi antara pemerintah pusat dan daerah. Urusan inilah yang diserahkan oleh pemerintah pusat kepada pemerintah daerah sebagai dasar dilaksanakannya otonomi daerah. Urusan konkuren pemerintah daerah dibagi dalam dua kewenangan yaitu urusan pemerintahan wajib dan urusan pemerintahan pilihan.

Urusan pemerintahan wajib dibagi dalam urusan pemerintahan yang berkaitan dengan pelayanan dasar seperti pendidikan, kesehatan, pekerjaan umum dan penataan ruang, perumahan rakyat dan kawasan pemukiman, ketentraman, ketertiban umum, dan perlindungan masyarakat serta pelayanan sosial. Kedua, urusan pemerintahan yang tidak berkaitan dengan pelayanan dasar seperti tenaga kerja, pemberdayaan perempuan dan perlindungan anak, pangan, pertanahan, lingkungan hidup, administrasi kependudukan dan pencatatan sipil, serta pemberdayaan masyarakat dan desa, dll.

Urusan pemerintahan pilihan meliputi urusan pemerintahan yang nyata ada dan berpotensi untuk meningkatkan kesejahteraan masyarakat sesuai dengan kondisi, kekhasan, dan potensi suatu daerah. Urusan ini meliputi kelautan dan perikanan, pariwisata, pertanian, kehutanan, dll. Pemerintah daerah memiliki kewenangan penuh untuk mengembangkan potensi daerah yang dimilikinya, sehingga melalui potensi tersebut dapat meningkatkan pembangunan daerahnya.

Urusan pemerintahan merupakan urusan pemerintahan yang menjadi kewengan mutlak presiden sebagai kepala negara. Urusan ini meliputi pembinaan wawasan kebangsaan dan ketahanan nasional, pembinaan persatuan dan kesatuan bangsa, pembinaan kerukunan antarsuku, agama, ras dan golongan, penangan konflik, dll. Dalam urusan ini presiden dapat menunjuk kepala daerah sebagai penanggungjawab 
pelaksanaan urusan umum dan bertanggungjawab langsung kepada presiden melalui menteri.

Keberadaan industrialisasi sebagai alternatif jawaban bagi pertumbuhan dan pembangunan ekonomi sebuah daerah memberikan dampak yang beragam bagi daerah itu sendiri. Peningkatan pertumbuhan ekonomi dan pembangunan daerah menjadi indikator utama didorongnya proses industrialisasi secara terus menerus. Akan tetapi, semakin derasnya arus industrialisasi meninggalkan dampak yang memprihatinkan, salah satunya adalah limbah industri.

Limbah (Ginting, 2007) mengartikan sebagai buangan yang kehadirannya pada suatu saat dan tempat tertentu tidak dikehendaki lingkungannya karena tidak mempunyai nilai ekonomi. Limbah yang mengandung bahan polutan memiliki sifat racun dan berbahaya dikenal dengan istilah limbah B3, yaitu limbah yang bahannya berjumlah relatif sedikit tetapi berpotensi untuk merusak lingkungan hidup dan sumberdaya. Limbah industri yang dimaksud dalam penelitian ini adalah debu batu bara yang dihasilkan oleh PT. Mifa Bersaudara.

Debu batubara adalah material batubara yang terbentuk bubuk (powder), yang berasal dari hancuran batubara ketika terjadi pemrosesannya (breaking, blending, transporting, and weathering), debu batubara juga dapat meledak apabila terambang di udara sekitarnya (Cyntia, 2011). Hal ini menjadi perhatian yang cukup penting bagi industri secara matang memperhitungkan dampak yang muncul dari penambangan batubara tersebut.

Debu batubara (Cyntia, 2011) berasal dari kegiatan penambangan yang dilakukan oleh industri itu sendiri, akan lebih banyak menghasilkan debu apabila proses pemisahan (breaking) secara kering melalui peledakan penggaruan. Selain itu, debu batubara juga terbentuk pada proses penggilingan dan ketika pencampurannya serta proses pelapukan alami batubara. Berbagai faktor yang berasal dari pemrosesan batubara pada dasarnya berpotensi besar menyumbangkan debu batubara dalam jumlah besar juga.

Cyntia (2011) lebih lanjut menjelaskan beberap dampak kesehatan yang disebabkan oleh debu batu bara, yaitu pneumokoniosis batubara (coal pneumokoniosis), bronkitis kronik, asma kerja, dan chronic obstructive pulmonary disease (COPD). Jenis penyakit pneumokoniosis batubara (coal pneumokoniosis), bronkitis kronik, dan asma kerja adalah jenis penyakit yang diidap oleh penambang batubara. Sedangkan COPD adalah penyakit yang menjangkiti masyarakat sekitar daerah penambangan.

Edmonton (2010) menjelaskan bahwa COPD mengakibatkan dua jenis penyakit yang lebih spesifik yatu chronic bronchitis dan emphysema. Gejala yang timbul dari penyakit ini adalah penurunan angka restriktif pada saat pemeriksaan paru dan nafas 
yang terputus-putus juga pendek. Penurunan fungsi paru timbul saat terjadi peningkatan jumlah paparan batubara dalam tubuh, akan semakin bahaya apabila kebiasaan merokok dan gaya hidup tidak sehat dijalankan oleh mereka yang menderita penyakit ini.

Penanganan yang tidak tepat bahkan kelalaian dalam pengelolaan batubara akan menyebabkan peningkatan jumlah debu batubara setiap waktunya. Apabila hal tersebut dibiarkan dan tidak ditangani secara maksimal akan terus menganggu kesehatan masyarakat di sekitar lokasi penambangan. Penanganan debu batubara bukan hanya menjadi tanggung jawab industri tetapi juga pemerintah bersama masyarakat.

\section{METODE PENELITIAN}

Penelitian ini menggunakan pendekatan kualitatif (Moleong, 2002) yaitu penelitian yang tidak menggunakan perhitungan tetapi menekankan kepada karakter alamiah sumber data. Penelitian ini akan disajikan dalam bentuk deskripsi dengan cara menganalisis sebuah fenomena mengenai bahaya debu batubara PT. Mifa Bersaudara yang mengakibatkan gangguan kesehatan pada masyarakat di sekitar lokasi industri dan menganalisis peran pemerintah Aceh Barat dalam mengatasi permasalah tersebut. Jenis penelitian ini adalah studi kasus yang bersifat analisisdeskriptif berupa kata-kata tertulis atau lisan dari keadaan yang diamati terutama berkaitan dengan peran pemerintah Aceh Barat dalam mengatasi limbah industri PT. Mifa Bersaudara.

Lokasi penelitian ini berada di daerah Kabupaten Aceh Barat Provinsi Aceh. PT. Mifa Bersaudara terletak di wilayah paling ujung selatan Kabupaten Aceh Barat yang langsung berbatasan langsung dengan Kabupaten Nagan Raya. PT. Mifa Bersaudara merupakan industri yang mengelola batubara dan merupakan anak perusahaan dari PT. Media Djaya Bersama. Data dalam penelitian ini dikumpulkan menggunakan instrumen pengumpulan data berupa observasi, wawancara dan dokumentasi. Data penelitian ini terdiri dari dua bagian, yaitu data primer dengan teknik observasi maupun wawancara dan data sekunder yang berupa dokumen, arsip, buku, artikel, dll. Serta, subjek penelitian untuk mendapatkan informasi adalah pemerintah Aceh Barat yang memiliki kewenangan untuk membuat dan mengambil kebijakan terkait persoalan debu batubara yang disebabkan oleh aktivitas pertambangan PT. Mifa Bersaudara.

Analisis data penelitian ini menggunakan teknik deskriptif kualitatif, yaitu teknik menganalisis data menggunakan penggambaran, penuturan, dan menguraikan data yang bersifat kualitatif. Adapun langkah-langkah analisis data dalam penelitian ini meliputi : 
1. Mencatat dan menelaah hasil dari data yang telah diperoleh dari berbagai sumber.

2. Mengumpulkan, memilah, mensitesis, mengikhtisar dan mengklasifikasikan data sesuai rumusan masalah.

3. Data yang telah dikategorikan kemudian di analisis untuk mencari makna, hubungan dan mengaitkan temuan-temuan yang sudah ada dengan rumusan masalah.

Analisis data kemudian di uji keabsahannya untuk mendapatkan data yang valid menggunakan teknik Trianggulasi, yaitu sumber data yang sudah ada dibandingkan keakuratnnya dengan metode yang dipilih kemudian dibandingkan kembali dengan penelitian lainnya.

\section{HASIL PENELITIAN DAN PEMBAHASAN}

Keluhan masyarakat terhadap limbah debu batubara PT. Mifa Bersaudara muncul sejak difungsikannya stockpile (tempat penyimpanan) batu bara yang jaraknya hanya 20 meter dengan pemukiman masyarakat. akibat jarak yang terlalu dekat ini menyebabkan berbagai persoalan dalam aktivitas sehari-hari masyarakat seperti debu batubara yang mengotori rumah hingga peralatan dapur dan mengkontaminasi makanan yang tidak disimpan dalam tempat tertutup, menganggu barang dagangan masyarakat yang menajdi kotor akibat ditutupi debu batubara hingga persoalan kesehatan yang menyebabkan berbagai macam gangguan pernapasan, gangguan paru-paru, asma dan banyak lagi.

Pemerintah Aceh Barat terus berupaya untuk mengatasi persoalan limbah industri terutama persoalan debu batu bara akibat proses penambangan batu bara yang dilakukan oleh PT. Mifa Bersaudara. Hal ini dilakukan karena menindaklanjuti keluhan yang disampaikan oleh masyarakat Gampong Peunaga Cut Ujong yang sebagian besar mengeluhkan pencemaran lingkungan akibat debu batu bara yang menganggu aktivitas dan kesehatan mereka, sehingga masyarakat merasa tidak nyaman dalam beraktivitas.

Tahun 2017, perwakilan Dinas Energi Sumber Daya Mineral (ESDM) Provinsi Aceh telah merilis hasil kajian lapangan mengenai persoalan debu batu bara PT. Mifa Bersaudara. Dalam kajian tersebut didapati fakta bahwa debu batu bara PT. Mifa Bersaudara telah mencemari pemukiman tempat tinggal masyarakat, karena jangkauan debu dengan rumah masyarakat sangat dekat. Adapun debu batu bara berasal dari stockpile batu bara PT. Mifa Bersaudara yang jaraknya terlalu dekat dengan pemukiman warga.

Pemerintah Aceh Barat melalui instansi terkait seperti Satuan Kerja Pemerintah Kabupaten (SKPK) Aceh Barat, perwakilan ESDM Provinsi Aceh, 
perwakilan aktivis lingkungan hidup Kabupaten Aceh Barat, perwakilan PT. Mifa Bersaudara dan masyarakat yang menjadi korban telah melaksanakan Rapat Dengar Pendapat (RDP) mengenai berbagai macam permasalahan yang dirasakan oleh masyarakat terdampak debu batubara serta melakukan Analisa Dampak Lingkungan (AMDAL) di lokasi PT. Mifa Bersaudara.

Upaya lain yang dilakukan oleh Pemerintah Aceh Barat adalah dengan membentuk panitia khusus (pansus) yang dipimpin langsung oleh Ketua Dewan Perwakilan Rakyat Kabupaten (DPRK) Aceh Barat, Ramli dan anggota dari Komisi B DPRK Aceh Barat. Pembentukan pansus ini diharapkan mampu untuk menyelesaikan persoalan penanganan debu batubara yang sudah sangat meresahkan masyarakat. Penanganan debu batubara ini menjadi prioritas pemerintah dan instansi lain yang terkait, namun peran serta PT. Mifa Bersaudara dalam melaksanakan tanggungjawab Coorporate Social Responsibility (CSR) juga perlu ditekankan karena penyelesaian masalah hanya akan tercapai apabila segenap kalangan saling mendukung.

Hasil kajian yang dilakukan oleh pansus DPRK Aceh Barat menemukan bahwa PT. Mifa Bersaudara cenderung mengabaikan protokol dalam pelaksanaan penambangan. Hal ini dikarenakan dari hasil inspeksi pansus ke lapangan, PT. Mifa Bersaudara masih banyak dijumpai ketidaklayakan dalam proses penambangan sehingga menyebabkan timbulnya permasalahan debu batubara. Selain itu, pansus menilai bahwa Pemerintah Aceh Barat telah lalai dalam melakukan pembinaan dan pengawasan terhadap PT. Mifa Bersaudara, karena hingga saat ini PT. Mifa Bersaudara masih banyak menerima kritikan dari masyarakat mengenai prosedur kerja yang cenderung merugikan masyarakat di sekitar lokasi industri.

Sulitnya akses pemerintah hingga masyarakat untuk mengkaji proses penambangan batu bara secara langsung di PT. Mifa Bersaudara menambah panjang daftar hambatan untuk mengoptimalkan upaya penangangan debu batubara. Hal ini mengindikasikan bahwa PT. Mifa Bersaudara cenderung tertutup dalam merespon permasalahan yang menyangkut industrinya tersebut. Padahal masyarakat di sekitar lokasi industri terdampak debu batubara hanya menginginkan kesepakatan antar kedua belah pihak yang difasilitasi oleh Pemerintah Aceh Barat sehingga memberikan solusi terbaik bagi masyarakat dan keberlanjutan industri PT. Mifa Bersaudara.

Masyarakat terdampak bedu batubara mengiinginkan dilakukannya relokasi tempat tinggal mereka ke lokasi lain yang jauh dari penambangan. Hal ini terjadi karena masyarakat menilai bahwa penanganan mengenai permasalahan debu batubara oleh Pemerintah Aceh Barat tidak membawa hasil, serta masyarakat sudah merasa 
sangat terganggu dalam beraktivitas dan kesehatan yang tidak terjamin apabila harus terus menetap dilokasi sekitar industri.

Ketidaktegasan Pemerintah Aceh Barat dalam menanggapi keluhan masyarakat terhadap kegiatan penambangan PT. Mifa Bersaudara mengakibatkan krisis kepercayaan masyarakat terhadap kinerja Pemerintah Aceh Barat. Dalam Peraturan Pemerintah Nomor 55 Tahun 2010, Pasal 2 Ayat (2) secara tegas dinyatakan bahwa "Menteri, Gubernur, Bupati/Walikota sesuai dengan kewenangannya melakukan pembinaan atas pelaksanaan kegiatan usaha pertambangan yang dilaksanakan oleh pemegang IUP, IPR, atau IUPK”. Berdasarkan peraturan tersebut, Pemerintah Aceh Barat memiliki kewenangan yang sah untuk melakukan pengawasan dan mengevaluasi kerja PT. Mifa Bersaudara.

Pemerintah secara tegas memiliki kuasa untuk mengambil sikap terhadap kerugian yang dialami oleh masyarakat akibat aktivitas pertambangan yang memunculkan permasalahan debu batubara. Sebagai pengawas, Pemerintah Aceh Barat harus mampu untuk menjalin kerja sama dan membangun kesadaran PT. Mifa Bersaudara mengenai dampak yang ditimbulkan dari kegiatan industrialisasi PT. Mifa Bersaudara, dalam hal ini Pemerintah Aceh Barat dapat memberikan teguran maupun sanksi yang mampu memberi efek jera bagi pelanggaran aturan yang dilakukan dari kegiatan pertambangan.

Ketegasan Pemerintah Aceh Barat dalam menindaklanjuti pelanggaran oleh PT. Mifa juga harus dibarengi dengan iktikad baik dari PT. Mifa Bersaudara sendiri untuk saling mendukung terciptanya proses industrialisasi yang baik. Namun, sikap dan sulitnya akses untuk masuk ke lokasi pertambangan oleh pihak PT. Mifa Bersaudara menyebabkan Pemerintah Aceh Barat mengalami hambatan untuk memaksimalkan jalan keluar dari persoalan yang terjadi. Undang-undang Nomor 32 Tahun 2009 Pasal 70 Ayat (1) menegaskan bahwa masyarakat memiliki hak dan kesempatan yang sama dan seluas-luasnya untuk berperan aktif dalam perlindungan dan pengelolaan lingungan hidup dan pada Ayat (2) dinyatakan bahwa peran tersebut berupa pengawasan sosial, pemberian saran, pendapat, usul, keberatan, pengaduan, dan atau penyampaian informasi atau laporan.

Undang-undang secara jelas telah mengatur bahwa masyarakat memiliki peran penting dan akses untuk ikut menyuarakan mengenai pengelolaan lingkungan hidup. Terlebih lagi, dalam pengelolan lingkungan hidup tersebut secara khusus melibatkan kehidupan masyarakat itu sendiri, seperti kerusakan lingkungan akibat debu batubara yang terjadi pada masyarakat di Gampong Peunaga Cut Ujong Aceh Barat. Keluhan, protes dan aksi yang dilakukan masyarakat serta tuntutan masyarakat terhadap Pemerintah untuk mendapatkan kembali kehidupan layak sudah seharusnya diperjuangkan oleh Pemerintah Aceh Barat. 
Berbeda dengan tanggapan masyarakat yang menilai kinerja Pemerintah Aceh Barat yang lamban, PT. Mifa Bersaudara telah melakukan berbagai upaya untuk mengurangi dampak debu batubara dengan memasang jaring penahan debu disekitar lokasi industri, melakukan penyiraman disekitar pemukiman masyarakat yang dilalui oleh lintasan kendaraan pengangkutan batubara, penanaman pohon disekitar lokasi industri dan pemukiman masyarakat, serta pemasangan pagar batas industri dengan pemukiman masyarakat yang dilengkapi dengan sistem penyaring udara otomatis untuk menangkal debu batubara.

PT. Mifa Bersaudara melalui penggunaan CSR juga telah melaksanakan program sosial yaitu membuka klinik kesehatan dan pengobatan gratis setiap dua minggu sekali yang bekerja sama dengan Dinas Kesehatan Kabupaten Aceh Barat. Selain itu, program sosial kemasyarakatan lainnya seperti di bidang pendidikan juga turut dilaksanakan oleh PT. Mifa untuk memberikan edukasi mengenai persoalan pencemaran lingkungan kepada masyarakat.

Masyarakat Gampong Peunaga Cut Ujong sebagai salah satu gampong yang menerima program CSR PT. Mifa Bersaudara merasakan beberapa manfaat positif dari keberadaan industri tersebut, seperti dalam bidang kesehatan dilaksanakannya pengobatan gratis, pembagian obat-obatan gratis dan penyelenggaraan posyandu bagi ibu hamil dan anak-anak, di bidang pendidikan, diberikan santunan kepada anak-anak kurang mampu, di bidang sosial penyelenggaraan gotong royong membersihkan gampong rutin dilaksanakan, serta di bidang ekonomi dilaksanakannya pembagian bibit tanaman, pupuk tanaman, pemberian bebek untuk ternak, serta dibangunnya taman hidroponik.

Berbagai macam bentuk program kerja PT. Mifa Bersaudara belum mampu untuk menghentikan tuntutan masyarakat Gampong Peunaga Cut Ujong untuk direlokasi. Karena bagi masyarakat, berbagai bantuan yang menajdi program PT. Mifa Bersaudara tidak mampu untuk menutupi ketidaknyamanan mereka yang harus hidup setiap harinya dengan menghirup udara yang kotor. Atas dasar pertimbanga tersebut, masyarakat hingga saat ini tetap mengupayakan agar keinginan mereka dapat tercapai dengan difasilitasi oleh Pemerintah Aceh Barat.

\section{SIMPULAN}

Pemerintah Aceh Barat belum berperan aktif dalam upaya untuk mengatasi persoalan limbah debu batubara di sekitar PT. Mifa Bersaudara. Hal ini dibuktikan dengan belum adanya respon positif dari PT. Mifa Bersaudara terhadap solusi yang diberikan oleh masyarakat terdampak debu batubara di sekitar lokasi industri. Ketiadaan respon dari PT. Mifa Bersaudara terhadap keluhan masyarakat menunjukkan bahawa Pemerintah Aceh Barat belum efektif dan efesien dalam menyelesaikan persoalan debu batubara tersebut. 
Peran Pemerintah Aceh Barat yang tidak maksimal dalam penyelesaian permasalahan debu batubara antara PT. Mifa Bersaudara dengan masyarakat akan menimbulkan konflik sosial yang menjadi duri yang mencederai kinerja pemerintah. pemerintah harus mampu mengambil tindakan tegas terhadap pelaku industri yang dalam pelaksanaan kegiatan industrinya terjadi penyelewengan yang merugikan masyarakat luas.

Peran Pemerintah Aceh Barat dalam menangani persoalan sosial kemasyarakatan juga tidak akan maksimal apabila tidak disertai dengan dukungan dari pihak industri maupun masyarakat itu sendiri. Perlu dibentuk sebuah kesadaran bahwa proses pembangunan tidak akan berhasil tanpa adanya koalisi dari seluruh elemen, yaitu pemerintah, swasta dan masyarakat. Hal ini hanya akan tercapai apabila pemerintah mampu mengelola suatu program yang dapat membangun kesadaran tersebut, terutamanya melalui edukasi dalam penanganan limbah industri baik kepada masyarakat maupun kepada pihak industri.

\section{DAFTAR PUSTAKA}

Amrianto. 2015. Peranan Elit Tradisional Dalam Dinamika Politik Lokal Pada Pemilihan Kepala Daerah di Kabupaten Wakatobi 2014. Jurnal Politico. Volume 1, No. 7.

Cyntia Galuh Puspita. 2011. Pengaruh Paparan Debu Batubara Terhadap Gangguan Faal Paru Pada Pekerja Kontrak Bagian Coal Handling PT PJB Unit Pembangkitan Paiton (skripsi). Jember: Universitas Jember.

Dwi Cahyono. 2008. Persepsi Ketidakpastian Lingkungan, Ambiguitas Peran dan Konflik Peran Sebagai Mediasi Antara Program Mentoring Dengan Kepuasan Kerja, Prestasi Kerja dan Niat Ingin Pindah: Studi Empiris di Lingkungan Kantor Akuntan Publik (KAP) Besar (Disertasi). Universitas Diponegoro.

Edmonton. 2010. Coal Dust at The Work Site. New York: Work Safe Alberta.

Gartiria Hutami \& Anis Chariri. 2011. Pengaruh Konflik Peran dan Ambiguitas Peran Terhadap Komitmen Independensi Auditor Internal Pemerintah Daerah (Studi Empiris Inspektorat Kota Semarang) (Thesis). Universitas Diponegoro.

https://kbbi.web.id/peran (diakses pada Senin, 21 Agustus 2018, pukul 10.00 WIB).

Ima Maghfiro, dkk. Analisis Peran Pemerintah dalam Mengatasi Limbah Industri Pabrik Gula Tjoekir. Jurnal Administrasi Publik. Vol. 1, Nomor 3. H. 94102.

Lexi J, Moleong. 2002. Metodelogi Penelitian Kualitatif. Bandung: PT. Remaja Rosda Karya.

Perdana Ginting. 2007. Sistem Pengelolaan Lingkungan dan Limbah Industri. Bandung: Yrama Widya.

Siahaan. Hukum Lingkungan. Jakarta: Pancur Alam. 2008.

Sheriff F. Folarin. 2010. National Role Conceptions and Nigeria's African Policy (19852007) (Unpublished PhD Thesis). Ota: Covenant University.

Undang-undang Nomor 32 Tahun 2009 Tentang Perlindungan dan Pengelolaan Lingkungan Hidup

Undang-undang Nomor 23 Tahun 2014 Tentang Pemerintahan Daerah. 
Jurnal Public Policy

Volume 5, Nomor 1, April 2019

Peraturan Pemerintah Nomor 55 Tahun 2010 Tentang Pembinaan dan Pengawasan Penyelenggaraan Pengelolaan dan Pelaksanaan Usaha Pertambangan Mineral dan Batubara 